\title{
The Role of Local Village Facilitators in Empowerment in Medan Estate Village, Percut Sei Tuan District, Deli Serdang Regency
}

\author{
Tomshon Manapar Purba ${ }^{1}$, R. Hamdani Harahap ${ }^{2}$, Heri Kusmanto ${ }^{3}$ \\ 1,2,3Universitas Sumatera Utara, Indonesia. \\ Corresponding Author: Tomshon Manapar Purba
}

\begin{abstract}
The limitations of the village in management in various sectors, both in the economic, health, education and infrastructure sectors make the village the main focus of the government in implementing development. Based on Law Number 6 of 2014 concerning villages, making villages have an important role in the implementation of development and empowerment. One of the implementations of the village law is by issuing village fund programs that are prioritized in achieving sustainable development goals (SDGs). To assist the government in accelerating the achievement of the SDGs, the Minister of Villages, Development of Disadvantaged Regions and Transmigration Regulations Number 19 of 2020 concerning Amendments to the Regulation of the Minister of Villages, Development of Disadvantaged Regions and Transmigration Number 18 of 2019 concerning General Guidelines for Assisting Village Communities has been presented. Medan Estate Village is located in Percut Sei Tuan District, Deli Serdang Regency. Community empowerment can be carried out by local village assistants who assist in facilitating the achievement of SDGs data collection starting from socialization to inputting data on applications. The purpose of this study was to determine the role of local village facilitators in assisting empowerment activities in Medan Estate Village. This research method is descriptive qualitative research. The results of this study indicate that the role of local village assistants in facilitating the village government runs according to its duties but in empowering the community it has not run optimally. The
\end{abstract}

supporting factor in mentoring is the openness of the village government in establishing cooperation and the obstacle in mentoring is the lack of village community participation in village meetings.

Keywords: Local Village Facilitators, Empowerment, Sustainable Development Goals

\section{INTRODUCTION}

The limitations of the village in management in various sectors, both in the economic, health, education and infrastructure sectors make the village the main focus of the government in implementing development. The government's efforts in presenting community empowerment and village development programs have a goal to improve the welfare of the community as seen from the increase in living standards.

Based on Law Number 6 of 2014 concerning villages, making villages have an important role in the implementation of development and empowerment. Rural development has an important role that can strengthen the foundation of the country's economy. Rural development will accelerate poverty reduction and regional disparities. The village is a legal community unit that has territorial boundaries, which is authorized to regulate and manage the interests of the local community that are recognized and respected in the system of the Government of the Unitary State of the Republic of Indonesia. In the current 
Indonesian government system, villages have important authority to assist local governments in implementing development and empowerment.

One of the implementations of the village law is by issuing village fund programs that are prioritized in achieving sustainable development goals (SDGs).

To assist the government in accelerating the achievement of the SDGs, the Minister of Villages, Development of Disadvantaged Regions and Transmigration Regulations Number 19 of 2020 concerning Amendments to the Regulation of the Minister of Villages, Development of Disadvantaged Regions and Transmigration Number 18 of 2019 concerning General Guidelines for Assisting Village Communities has been presented.

Assistance personnel are people or institutions that carry out mentoring tasks in community empowerment activities who have knowledge, skills and experience in the field of empowerment (Dianto, 2018). In the implementation of mentoring activities carried out by village assistants in accordance with Government Regulation Number 47 of 2015 concerning Amendments to Government Regulation Number 43 of 2014 concerning Implementing Regulations of Law Number 6 of 2014 concerning Villages. The assistant is here to assist the government in facilitating the community in the village. Mentoring activities are focused on managing development and empowering rural communities through development programs and village community empowerment which are carried out from the planning stage to finalizing accountability in accordance with the village law.

Village assistants are not the main actors in the development planning process and do not have the authority as determinants, but assistants are facilitators who are required to have good perspectives and work skills. In today's era, the name of a professional assistant or village assistant is familiar to our ears and the wider community, because the name of the village assistant is never separated from its relation to empowerment in the village. The relationship between village facilitators and empowerment is often seen as a village facilitator whose job is to help and facilitate the village to become a more developed, stronger, independent and democratic village. Village facilitators are not only accompanying every project implementation in the village, and not only accompanying and supervising the management and use of village funds, but village assistants also have an important role in carrying out full mentoring activities for their assisted villages. There is not a little news that leads to the performance of assistants related to the village fund, assistant staff often become agents who interfere in the implementation of the village fund program, in other words, assistants try to find profits in order to increase their income. One of them happened in Aceh Province, several village assistants who were caught participating in the preparation of the draft revenue and expenditure budget document were immediately dismissed.

The role of local village assistants as volunteer coordinators in supporting the success of updating the Village SDGs data collection not only informs about policy developments from the Ministry of Villages, Development of Disadvantaged Regions, and Transmigration but also provides direction and motivation for the Village Government. In assisting and providing direction and motivation to the village government and the community, it will greatly affect the success of the village SDGs data collection. the local village assistant is one of the facilitators who helps in the progress of the SDGs data collection. His role as a facilitator is required to be able to explain the process of updating the village SDGs data and monitoring the entire process of updating the village SDGs data. With the SDGs, it is hoped that all aspects of development can be felt by villagers without being missed. SDGs-based village development leads to eighteen sustainable 
development goals. With the source of funds provided to villages, the government prioritizes the use of village funds directed at accelerating the achievement of SDGs through national economic recovery in accordance with village authority.

Medan Estate Village is located in Percut Sei Tuan District, Deli Serdang Regency. Community empowerment can be carried out by local village assistants who assist in facilitating the achievement of SDGs data collection starting from socialization to inputting data on applications.

The purpose of this study was to determine the role of local village facilitators in assisting empowerment activities in Medan Estate Village.

\section{LITERATURE REVIEW Role}

Role according to Soekanto (2002:243), is a dynamic aspect of position or status, which means that if someone has carried out his rights and obligations according to his position, that person has carried out a role. Role and position cannot be separated between position and role because they are mutually dependent on each other. If there is no role then there is no position, so there is no position then there is no role. In an organization, everyone has various characteristics in carrying out the duties, obligations or responsibilities that have been given by each organization or institution. The role can be carried out in accordance with the authority, power and facilities owned according to the position. The role is a characteristic possessed by an actor who is brought on a drama stage, in a social sense the role is a function that is owned by a person when he is in a position in the social structure. According to Elder in (Sarwono, 2011:89) role theory describes the social relationships carried out by actors according to culture.

Apart from the above theory, there is also a theory which states that the role is a concept of the part carried out by individuals or groups who behave in accordance with the expectations of the surrounding environment (Riyadi, 2002:138). Role is a series of certain behaviors that arise from a certain level. Roles can also be interpreted as a set of behaviors with groups, both small and large. Apart from that, what affects the role that can be carried out is seen from a person's personality.

\section{Village Assistant}

Village assistants are professionals that are recruited directly under the auspices of the Ministry of Villages, Development of Disadvantaged Regions and Transmigration. The government in carrying out the mentoring function, in accordance with the Minister of Village Regulation, Development of Disadvantaged Regions and Transmigration Number 18 of 2019, gives its authority to professional assistants, community development cadres or third parties. The assistance referred to above is a village assistant who has the following positions:

a. Village Facilitator who is domiciled in the sub-district.

b. Technical Assistant based in the district.

c. Community Empowerment Experts are domiciled at the center and in the provinces.

Meanwhile, what is meant by third parties are among others:

a. Non-governmental organization.

b. College.

c. Social Organization.

d. Company.

\section{The Role of Local Village Facilitators in Community Empowerment}

As explained above, the role is the rights and obligations of someone who has been carried out. So that when someone has carried out his rights and obligations, then his role has been carried out. Village local assistants have a role to provide assistance in administering government in the village. The abilities that must be possessed in carrying out their duties as local village assistants must have qualifications and 
competencies in carrying out their duties. In this case, to be a local village assistant, one must have competence in the field of community empowerment, this is a top priority in selecting local village assistants. The goal is that local village assistants's experience can be implemented into work plans and budgets in the villages they assist.

In accordance with the Regulation of the Minister of Villages, Development of Disadvantaged Regions and Transmigration Number 3 of 2015 the objectives of the assistance are:

1. Optimizing village local assets in an emancipatory manner.

2. Increase the capacity, effectiveness, and accountability of village government and village development.

3. Increasing the synergy of inter-sectoral village development programs.

4. Increase the initiative, awareness and participation of rural communities in participatory village development.

\section{Community Empowerment}

Community empowerment can be interpreted as providing opportunities for every community to be able to participate and have the right to make decisions related to development carried out in the village. Empowerment is an effective way to improve the welfare and life of rural communities. With the assistance carried out in community empowerment, it is expected to be able to encourage the ability and creativity of the community. Empowerment is a force against the community, so that an independent community must be given the power to explore the potential and resources in the village. Community empowerment is an effort that can take part in the delivery of open aspirations and interests.

Community empowerment is an effort to give power so that the voice of the community can be heard so that they can contribute to planning and implementation. Community empowerment has the aim of being able to shape individuals and communities to become independent. The independence in question is people who can think independently and act and control the activities they do. In addition, village community empowerment is carried out to develop community independence and welfare by increasing knowledge, attitudes, skills, behavior, abilities, awareness. Village community empowerment has the aim of providing opportunities for villages to take collective action by involving the community in the interests of those in the village, so that the community can participate in activities carried out in the village. So that it can also involve village communities in the village development process, compiling development plans through village meetings.

\section{Supporting and Inhibiting Factors in Implementing Community Empowerment in Medan Estate Village}

In the implementation of community empowerment, it provides opportunities for the community, so that the community can participate and have the same rights in making decisions and policies in implementing activities in the village. In implementing empowerment, the main goal is to be able to eradicate poverty in rural communities. Empowerment activities are activities that can make the community the main object that takes a role to realize aspirations and interests freely and protected. However, in empowerment there are always challenges or factors that support and hinder the mentoring process. The supporting factor in empowering rural communities is the openness of the village government to be able to work together with village assistants to carry out planning and development as well as community empowerment. Apart from that, the inhibiting factor in the implementation of community empowerment is the lack of participation of the village community in the Medan Estate village. Village community participation is needed in order to develop potential and problems in the implementation of activities. 


\section{RESEARCH METHODS}

This research method is descriptive qualitative research. Descriptive research is a type of research that aims to make a systematic, factual and accurate description of the facts and characteristics of the population of a particular area (Pandiangan et al., 2021). Qualitative research is research that is descriptive and tends to use analysis. Process and meaning are highlighted in qualitative research (Pandiangan, 2015).

Research subjects are objects or organisms, individuals who are used as sources of information needed in collecting research data (Pandiangan et al., 2018). Research subjects can also be interpreted as individuals who are used as sources of information needed in data collection. In this case, the subject of this research is local village assistants, village officials and village communities in Medan Estate Village, Percut Sei Tuan District, Deli Serdang Regency.

The results of the study are strongly influenced by the accuracy in determining the type and source of data. The following data collection is divided into two parts, namely primary data and secondary data. Data obtained directly from the object to be studied is primary data. Primary data can be obtained directly from the source or resource person, both verbally and by the actions of the person who is asked for information through interviews (Pandiangan, 2018). Informants are selected based on subjects who master the problem and have data related to research and are willing to provide it. Regarding data obtained from certain institutions or agencies, it is called secondary data, such as data from services related to assistance. Primary data is data that has been processed in the form of written reports or documents. For example, data from the Law on mentoring and community empowerment as well as regulations that discuss village assistance.

Data analysis is the method chosen by researchers in managing the data that has been obtained from the field. The data that has been collected is data that has not been processed still in the form of words or pictures which will then be processed to become good information (Tobing et al., 2018).

\section{RESULT}

\section{Medan Estate Village Overview}

Villages in accordance with Law Number 6 of 2014 are legal community units that have territorial boundaries that are authorized to regulate and manage government affairs, the interests of local communities based on community initiatives, origin rights or traditional rights that are recognized and respected in the Unitary State government system. Republic of Indonesia. In Percut Sei Tuan sub-district there are eighteen villages and two subdistricts, in the focus of this research the researcher focuses on the Medan Estate village.

Historically, the village of Medan Estate, which is located in the Percut Sei Tuan district, was formerly known as Kampung Kebun Pisang which was led directly by the village head who was directly elected by the local community. The village head is the first elected by the community. Furthermore, in 1940-1960 headed by a village head elected by the government. It is said that the village of Medan Estate is because the surrounding area is a plantation area which is directly adjacent to the city of Medan. At this time the Medan Estate area is an educational area, offices and business areas. This is evidenced by the number of universities as well as government buildings and warehousing and shopping areas. So that the status of Medan Estate Village is an Independent Village as seen from the Building Village Index.

Geographical location of Medan Estate village is geographically located at an altitude of $\pm 25 \mathrm{~m}$ above sea level. With an average rainfall of $\pm 0.5 \mathrm{~m} / \mathrm{second}$ and an average air temperature of $\pm 25^{\circ} \mathrm{C}$ to $32^{\circ} \mathrm{C}$. The distance from the village to the subdistrict is $\pm 3 \mathrm{Km}$, and the distance from the 
village to the Regency is $\pm 30 \mathrm{Km}$. The boundaries of the Medan Estate village in the north are bordered by Sampali Village and Laut Dendang Village, in the east by Bandar Khalipah Village, and in the south directly by the Medan City Government (Bandar Selamat Village and Tembung Village), and in the west bordering directly with the Medan City Government (Sidorejo Village and Indra Kasih Village).

Medan Estate has an area of approximately $790 \mathrm{Ha}$ or 7.9 Square Kilometers and is currently growing rapidly with various types of development that can improve the community's economy, such as the construction of the North Sumatra Provincial Government Multipurpose Building, the construction of the Medan Haji Hospital and the construction of educational facilities around the area. such as the Medan Area University, Medan State University campus, North Sumatra State Islamic University, Cinta Budaya school, Wilmar Bisnis Indonesia Campus. And those who are more supportive of the progress of the area since the construction of the CitraLand Gama City Complex and the MMTC Traditional Market.

\section{The Role of Local Village Assistants in Village Community Empowerment in Medan Estate Village}

Talking about roles, local village assistants must be able to know the stages of mentoring to assist village communities. In this case, the community must also be able to understand what the duties of a local village assistant are. The existence of local village assistants formed by the government is the implementation of Law Number 06 of 2014 concerning Villages. The regulation was issued directly by the Ministry of Villages, Development of Disadvantaged Regions and Transmigration in the village community empowerment program. The task given by the village government is to provide assistance that can help and direct the village community which can be conveyed through suggestions and ideas owned by the local village assistant and can guide the community in order to increase community empowerment so that the community participates more in development in the village. his village. According to Gitosaputro and Rangga (2015:76), the role of other local village facilitators is as a facilitator, animator and coordinator and motivator for the village community. The role of local village assistants can also assist in the implementation and development process through direct discussions with the community about the problems they face.

It can be concluded from the description above, the researchers chose to discuss the role of the companion as a facilitator and communicator in empowering village communities. Village local assistants are expected to become facilitators in order to assist and facilitate both the community and the village government. His role as a local village assistant must be able to implement policies that have been issued by the government in order to empower the community in an effort to carry out development in the village. Empowerment is carried out in order to alleviate poverty in the community, and to improve welfare and a more decent life than before. There is assistance provided by local village assistants to the community in order to encourage the ability and creativity of the community so that they can become an independent community. Village local assistants have a role to assist the village starting from the planning process, implementation of activities to the process of monitoring and evaluating activities in the village.

This study discusses the role of the village local facilitator in empowering the Medan Estate village community whose role is to become a facilitator and communicator. In terms of facilitation, local village facilitators can be resource persons who can provide information on government policies and other matters related to empowerment. Apart from being a facilitator, the local village facilitator can also be a communicator who is able to communicate 
Tomshon Manapar Purba et.al. The role of local village facilitators in empowerment in Medan Estate Village, Percut Sei Tuan District, Deli Serdang Regency.

well in conveying messages to the community and village government.

\section{The Role of Local Village Assistants as Facilitators}

In this case, the village assistant has the task of assisting the village government in village sustainable development goals (SDGs) data collection activities such as socializing the determination of SDGs policies through village meetings and the formation of working groups with the community, village heads, village heads and structures in the village. Socialization is the main stage and the next step is to arrange a work team to collect data in the village. In the implementation of this village deliberation, the village head becomes the leader to determine the village data collection volunteer working group which is stipulated in the village head's decree. Deliberations for the preparation of working groups are very important so that the work team carries out the flow of data collection stages based on village, hamlet, family heads and individuals to the maximum extent to obtain accurate data as a basis for the government in determining priority and sustainable development policies. At the time of conducting this research, a deliberation for the provision of SDGs data collection was in progress. Meanwhile, the socialization discussion and the establishment of a working group for collecting data on SDGs were carried out several months ago. However, researchers continued to explore information and discuss the role of village local assistant from the beginning of the socialization of the formation of the working group to data collection.

The results of this study indicate that the role of local village assistants in facilitating the village government runs according to its duties but in empowering the community it has not run optimally.

\section{Supporting and Inhibiting Factors in Mentoring}

Village community empowerment is a way to be able to develop community independence and welfare by increasing the knowledge and skills and awareness of the community itself so that they can see their potential. Apart from that, empowerment can also be concluded that it provides opportunities for rural communities to participate in participation and gain rights in decision-making and policies in development planning. Empowerment can reduce the poverty rate in the village and can prosper people's lives so they can run a better life.

With community empowerment, it is intended that the community does not only hope for government assistance. With community empowerment, they are required to be active to be able to see the potential around their lives that can be used as a source of community creative ideas. Apart from that, the community is also not used as the object of a development project, but the community can be the main supporter in development. In development planning, the community is the main element supporting the success of development, this is because the community is the main determinant in decision making. The community must still be involved in the planning process up to the implementation of development. Community empowerment and development are activities carried out by the government or community institutions so that the community gets information related to development in the village.

In line with what is expected is not always as expected, in empowerment there are also obstacles and obstacles faced in carrying out a plan. In carrying out their role, local village assistants must be able to realize the policies issued by the government. However, in carrying out assistance, one must face several factors, such as factors that can support the success of village assistants in implementing village community empowerment, namely the openness of the village government to local 
village assistants who work in the village. Not a few think that local village assistants are not able to establish relationships with the village government. Sometimes the government only cares about the internal village government without accepting input and advice from outside. In carrying out its role, village local assistants are often sidelined when the village government makes mistakes in development planning. Directly, the local village assistant does not have administrative rights in the village government, so that the local village assistant is only limited to facilitating the village government.

The supporting factor in mentoring is the openness of the village government in establishing cooperation and the obstacle in mentoring is the lack of village community participation in village meetings.

\section{CONCLUSION AND SUGGESTION}

The results of this study indicate that the role of local village assistants in facilitating the village government runs according to its duties but in empowering the community it has not run optimally. The supporting factor in mentoring is the openness of the village government in establishing cooperation and the obstacle in mentoring is the lack of village community participation in village meetings.

Based on the results of the research above, the researchers here provide input to the village local assistants in assisting the Medan Estate Village in empowerment in the Medan Estate Village, namely:

1. The role of local village facilitators in providing information to village communities is less than optimal. As a source of information and people who understand about empowerment in accordance with the rules, local village assistants should convey information to the community as well, not only to the village government.

2. The role of local village assistants in mobilizing community participation in participating in village deliberation is still not optimal. Its role as a driving force must be increased because community participation in village deliberations is very much needed, so that there is no misunderstanding between the community and the village government.

3. Therefore, local village assistants are expected to be able to provide direct assistance in the Medan Estate Village and take direct approaches to mingle with the community in the village so that good relations are established with the community in the village and carry out discussions with the village community such as conducting discussions with community organizations or with local youth in the Medan Estate Village.

\section{Acknowledgement: None}

\section{Conflict of Interest: None}

\section{Source of Funding: None}

\section{REFERENCES}

1. Dianto, Icol. (2018). Problematika Pendamping Desa Profesional dalam Pemberdayaan Masyarakat Desa di Kota Padangsidempuan. Jurnal, 18(2).

2. Gitosaputro, Sumaryo \& Rangga, Kardiyana K. (2015). Pengembangan dan Pemberdayaan Masyarakat: Konsep, Teori dan Aplikasinya di Era Otonomi Daerah. Yogyakarta: Graha Ilmu.

3. Pandiangan, Saut Maruli Tua. (2015). Analisis Lama Mencari Kerja Bagi Tenaga Kerja Terdidik di Kota Medan. Skripsi. Medan: Fakultas Ekonomi dan Bisnis, Program Studi Ekonomi Pembangunan, Universitas Sumatera Utara. https://www.academia.edu/52494724/Analis is_Lama_Mencari_Kerja_Bagi_Tenaga_Ker ja_Terdidik_di_Kota_Medan.

4. Pandiangan, Saut Maruli Tua. (2018). Analisis Faktor-faktor yang Mempengaruhi Penawaran Tenaga Kerja Lanjut Usia di Kota Medan. Tesis. Medan: Fakultas Ekonomi dan Bisnis, Program Studi Ilmu Ekonomi, Universitas Sumatera Utara. http://repositori.usu.ac.id/bitstream/handle/1 
Tomshon Manapar Purba et.al. The role of local village facilitators in empowerment in Medan Estate Village, Percut Sei Tuan District, Deli Serdang Regency.

23456789/10033/167018013.pdf?sequence= 1\&isAllowed $=\mathrm{y}$.

5. Pandiangan, Saut Maruli Tua, Rujiman, Rahmanta, Tanjung, Indra I., Darus, Muhammad Dhio, \& Ismawan, Agus. (2018). An Analysis on the Factors which Influence Offering the Elderly as Workers in Medan. IOSR Journal of Humanities and Social Science (IOSR-JHSS), 23(10), 76-79. DOI: 10.9790/0837-2310087679.

6. Pandiangan, Saut Maruli Tua, Resmawa, Ira Ningrum, Simanjuntak, Owen De Pinto, Sitompul, Pretty Naomi, \& Jefri, Riny. (2021). Effect of E-Satisfaction on Repurchase Intention in Shopee User Students. Budapest International Research and Critics Institute-Journal, 4(4), 77857791. DOI: https://doi.org/10.33258/birci.v4i4.2697.

7. Riyadi. (2002). Perencanaan Pembangunan Daerah Strategi Mengendalikan Potensi Ddalam Mewujudkan Otonomi Daerah. Jakarta. Gramedia.
8. Sarwono, Sarlito. (2011). Teori-teori Psikologi Sosial. Jakarta: PT. Raja Grafindo Persada.

9. Soekanto. (2002). Teori Peranan. Jakarta: Bumi Aksara.

10. Tobing, Murniati, Afifuddin, Sya'ad, Rahmanta, Huber, Sandra Rouli, Pandiangan, Saut Maruli Tua, \& Muda, Iskandar. (2018). An Analysis on the Factors Which Influence the Earnings of Micro and Small Business: Case at Blacksmith Metal Industry. Academic Journal of Economic Studies, 5(1), 17-23. https://www.ceeol.com/search/articledetail ?id=754945.

How to cite this article: Tomshon Manapar Purba, R. Hamdani Harahap, Heri Kusmanto. The role of local village facilitators in empowerment in Medan Estate Village, Percut Sei Tuan District, Deli Serdang Regency. International Journal of Research and Review. 2021; 8(12): 548-556. DOI: https://doi.org/10. 52403/ijrr.20211267 